\title{
A LIST OF THE ODONATA OF ATHABASCASAND DUNES PROVINCIAL WILDERNESS PARK, SK
}

\author{
GORDON E. HUTCHINGS, 971 Arundel Drive, Victoria, BC V9A 2C4 \\ E-mail: odonatas@uvic.ca
}

\section{Introduction}

Athabasca Sand Dunes Provincial Wilderness Park (ASDPWP) is situated on the south shore of Lake Athabasca in Saskatchewan. This 1,925 square kilometre park, created in 1986, features open sand sheets, active dunes, extensive pine/lichen forests and a wide variety of interspersed wetlands featuring large rivers, lakes and spruce bogs. ${ }^{2,6}$ Its variety of habitats situated in a remote, northern latitude are home to unique organisms found nowhere else, including at least nine endemic plants and one insect (Cicindela hirticollis athabascensis, the Athabasca race of the Beach Tiger Beetle ${ }^{1}$ ). Because so little is known of the invertebrate fauna, ${ }^{6}$ every collecting trip has produced new range extensions for many species and there is much yet to be discovered.

This article reports the results on the Odonata (Dragonfly and Damselfly) portion of a 14-day survey which took place from July 2 to July 15, 2004 at ASDPWP. Participants were Ron Hooper and myself. We collected insects from a variety of orders during this period but mainly concentrated on groups associated with aquatic habitats. The Odonata were my main focus, due to my familiarity with this order of insects in Saskatchewan. This preliminary list of species represents only the second survey for odonates in ASDPWP; the previous survey was done in $2002 .{ }^{4}$

\section{Methods and materials}

The survey was carried out on foot from a central base-camp along Thomson Bay between William Point and Beaver Point on the south shore of Lake Athabasca. All study sites were situated between the William River to the west and Cantara Lake/Beaver Point to the east. They included a river, large and small lakes, pine forest, dune slacks (partially vegetated sand dunes), ponds, a large fen/ bog complex as well as open sand dunes. Because travel was done completely on foot, specific areas deemed suitable for odonates were chosen within a 20 kilometre radius from base camp. Air photos and topographical maps were used in choosing which sites to visit in the limited time available. The air photos provided for the expedition were especially valuable for this. Information on the sites is given in Table 1.

Aerial nets were used to collect adults patrolling territory and mating at the perimeter of wetlands, and feeding in open, terrestrial habitats ranging from sand dunes to pine forests. Adults were collected during the warmer hours of the day when they are active which was between 9:00 a.m. and 7:00 p.m. approximately. Some dusk-feeding adults were collected up until 9:30 p.m.. Larvae were collected with aquatic insect nets.

Voucher specimens were collected for all species encountered at each site. Mating 
Table 1. Specific odonata collecting sites in 2004.

\begin{tabular}{|c|c|c|c|c|}
\hline $\operatorname{code}^{*}$ & lat./long. & elevation & Site description & Date \\
\hline ASDG(01) & $\begin{array}{l}\text { N59E05'00.53" } \\
\text { W109E07'18.10" }\end{array}$ & 215.2 & beach edge basecamp at Thomson Bay & $\begin{array}{l}\text { VII.02 } \\
\& 06\end{array}$ \\
\hline ASDG(02) & $\begin{array}{l}\text { N59E04'56.15" } \\
\text { W109E07'16.61" }\end{array}$ & 219.3 & pine forest behind base camp & VII.02 \\
\hline ASDG(03) & $\begin{array}{l}\text { N59E04'54.41" } \\
\text { W 109E06'25.82" }\end{array}$ & 218.3 & pine forest behind base camp and to the east & VII.03 \\
\hline $\operatorname{ASDG}(04)$ & $\begin{array}{l}\text { N59E05'24.94" } \\
\text { W109E03'01.04" }\end{array}$ & 224.8 & Flycatcher Pond in pine forest at Thomson Bay & VII.03 \\
\hline $\operatorname{ASDG}(05)$ & $\begin{array}{l}\text { N59E07'09.81" } \\
\text { W I08E55'25.07" }\end{array}$ & 223.2 & fen complex east of Cantara Lake & VII.03 \\
\hline $\operatorname{ASDG}(06)$ & $\begin{array}{l}\text { N59E04'43.00" } \\
\text { W109£07'16.48" }\end{array}$ & 239.3 & edge of pine forest and sand dune behind camp & VII.04 \\
\hline ASDG(07) & $\begin{array}{l}\text { N59E02'56.19" } \\
\text { W } 109 \mathrm{E} 05^{\prime} 07.98^{\prime \prime}\end{array}$ & 265.2 & small pond in dune slacks $\sim 4 \mathrm{~km}$ south of camp & VII.05 \\
\hline ASDG(08) & $\begin{array}{l}\text { N59E0I'00.21" } \\
\text { W109E01'54.62" }\end{array}$ & 289.7 & Robin Lk. $\sim 9 \mathrm{~km}$ south of base camp & VII.05 \\
\hline $\operatorname{ASDG}(09)$ & $\begin{array}{l}\text { N59E08'49.17" } \\
\text { W109E16'23.28" } \\
\end{array}$ & 213.1 & pond \& fen at north end of William Point & V11.07 \\
\hline $\operatorname{ASDG}(10)$ & \begin{tabular}{|l} 
N59E05'19.84" \\
W109E I 1'52.28" \\
\end{tabular} & 259.9 & thick pine forest south of tip of William Point & VII.07 \\
\hline $\operatorname{ASDG}(11)$ & \begin{tabular}{|l|} 
N59E03'57.65" \\
W109E $12^{\prime} 31.60^{\prime \prime}$
\end{tabular} & 224.8 & bog adjacent to William River & VII.07 \\
\hline $\operatorname{ASDG}(12)$ & $\begin{array}{l}\text { N59E05'00.92" } \\
\text { W I09E06'30.15" }\end{array}$ & 215.9 & small string bog along beach east of base camp & VII.09 \\
\hline $\operatorname{ASDG}(13)$ & $\begin{array}{l}\text { N59E06'04.69" } \\
\text { W108E56'43.08" }\end{array}$ & $2 \mathrm{I} 9.1$ & small ponds southwest of Cantara Lake & VII. 10 \\
\hline $\operatorname{ASDG}(14)$ & $\begin{array}{l}\text { N59E06'21.I2" } \\
\text { W108E55'43.26" }\end{array}$ & 209.2 & bogs south of Cantara Lake & VII.10 \\
\hline $\operatorname{ASDG}(16)$ & $\begin{array}{l}\text { N59E04'44.53" } \\
\text { W109E09'30.47" }\end{array}$ & 228.0 & pine forest between dunes in Thomson Bay & VII.I2 \\
\hline ASDG(I7) & $\begin{array}{l}\text { N59E02'39.28" } \\
\text { W109E1 1'49.96" }\end{array}$ & 220.0 & William River and adjacent pine forest & VII.12 \\
\hline (CANTAR) & \begin{tabular}{|l|} 
N59E07'34.49" \\
W108E55'49.70"
\end{tabular} & 222.9 & Cantara Lake & $\begin{array}{l}\text { VII.02 } \\
\& \mathrm{I0}\end{array}$ \\
\hline
\end{tabular}

\section{* brackets ( ) designate referenced abbreviated code}

pairs, and cannibalistic and other pairs in predator/prey interactions were kept together. Identification of specimens was carried out in the field using hand lenses and the collector's personal expertise. Further applicable and relevant literature was consulted once the collector returned home and comparisons were performed with personal holdings of other Odonata specimens. ${ }^{10,11,12}$ The specimens were immediately prepared and preserved using the latest known methods, and later deposited at the Royal Saskatchewan Museum in Regina. Confirmation was performed by a second odonatologist at the Royal British Columbia Museum before sending on to the musuem in Regina.

\section{Results and discussion}

In total, 31 species were recorded for 2004 , and in combination with the 22 species from the previous survey in 2002 , this produced a combined list of 34 different species now recorded for the area. ${ }^{3,4,5}$ 
Odonata suborders, families and species

suborder ZYGOPTERA - Damselflies

\begin{tabular}{|c|c|}
\hline Family CALOPTERYGIDAE - Broad-wing Damsels & \\
\hline Calopteryx aequabilis - Ebony Jewelwing & 11,17 \\
\hline \multicolumn{2}{|l|}{ Family LESTIDAE - Spreadwings } \\
\hline Lestes congener - Spotted Spreadwing & 9 \\
\hline Lestes disjunctus - Common Spreadwing & $\begin{array}{l}4,5,7,8,9,1112,13, \\
\text { 14, CANTAR }\end{array}$ \\
\hline Lestes dryas - Emerald Spreadwing & 10 \\
\hline \multicolumn{2}{|l|}{ Family COENAGRIONIDAE - Pond Damsels } \\
\hline Coenagrion interrogatum - Subarctic Bluet & $3,4,5,7,8,10,13,14$ \\
\hline Coenagrion resolutum - Taiga Bluet & $4,5,7,8,10,13,14$ \\
\hline Enallagma boreale - Boreal Bluet & $4,8,10,13$ \\
\hline Enallagma cyathigerum - Northern Bluet & 8, CANTAR \\
\hline Enallagma ebrium - Marsh Bluet & 13 \\
\hline Nehalennia irene - Sedge Sprite & $4,5,7,13,14$ \\
\hline \multicolumn{2}{|l|}{ suborder ANISOPTERA - Dragonflies } \\
\hline \multicolumn{2}{|l|}{ Family AESHNIDAE - Darners } \\
\hline Aeshna canadensis - Canada Darner & 17 \\
\hline Aeshna eremita - Lake Darner & every site \\
\hline Aeshna interrupta - Variable Darner & 1,13 \\
\hline Aeshna juncea - Sedge Darner & $1,10,11,16,17$ \\
\hline Aeshna sitchensis - Zigzag Darner & $1,2,8,9,10,13$ \\
\hline Aeshna subarctica - Subarctic Darner & 5,17 \\
\hline Aeshna tuberculifera - Black-tipped Darner & 5,14 \\
\hline Aeshna umbrosa - Shadow Darner & 1,17, CANTAR \\
\hline \multicolumn{2}{|l|}{ Family GOMPHIDAE - Clubtails } \\
\hline Ophiogomphus colubrinus - Boreal Snaketail & $2,11,17$ \\
\hline \multicolumn{2}{|l|}{ Family CORDULIIDAE - Emeralds } \\
\hline Cordulia shurtleff $i$ - American Emerald & $2,4,9,10,11,13,14$ \\
\hline Somatochlora albicincta - Ringed Emerald & 14,16 \\
\hline Somatochlora cingulata - Lake Emerald & $1,8,14,16$, CANTAR \\
\hline Somatochlora forcipata - Forcipate Emerald & 1 \\
\hline Somatochlora franklini - Delicate Emerald & $\begin{array}{l}1,2,6,8,10,11,12, \\
13,14,17, \text { CANTARA }\end{array}$ \\
\hline Somatochlora kennedyi - Kennedy's Emerald & 1 \\
\hline Somatochlora minor - Ocellated Emerald & $1,8,11$ \\
\hline Somatochlora walshii - Brush-tipped Emerald & $1,2,6,12,14,16,17$ \\
\hline Somatochlora whitehouse - Whitehouse's Emerald & $\begin{array}{l}1,8,10,11,12,13, \\
14, \text { CANTARA }\end{array}$ \\
\hline \multicolumn{2}{|l|}{ Family LIBELLULIDAE - Skimmers } \\
\hline Leucorrhinia borealis - Boreal Whiteface & 1 \\
\hline Leucorrhinia glacialis - Crimson-ringed Whiteface & $4,5,7,13$ \\
\hline Leucorrhinia hudsonica - Hudsonian Whiteface & $\begin{array}{l}1,2,3,4,5,6,7,8, \\
10,11,13\end{array}$ \\
\hline Leucorrhinia patricia - Canada Whiteface & 5, CANTAR \\
\hline Leucorrhinia proxima-Red-waisted Whiteface & $4,8,10$ \\
\hline Libellula quadrimaculata - Four-spotted Skimr & $1,4,7,9,10,11$ \\
\hline
\end{tabular}

Table 2. Odonata species and associated collecting sites. Common names are from the North American Odonata checklist. ${ }^{7}$ 
The list of species in Table 2 presents the combined species list of dragonflies thus far collected from ASDPWP from the 2002 and 2004 field trips. Listings have been broken down into taxonomic levels from sub-order, down to individual species and then treated separately.

The 2004 survey extended the ranges of several species in the province and contributed to the current knowledge available for the Odonata in Saskatchewan. ${ }^{8}$ ${ }^{9}$ The information in this report is based on observations of approximately 4000 individual odonates either collected and examined in-hand, or verified at close proximity on the wing or perched; 332 specimens representing 6 families were retained for the Royal Saskatchewan Museum. In most cases, only a few specimens of each species were collected from a given site and the number does not represent the abundance of that particular species documented there.

This survey provides a baseline for future searches for additional new and interesting records. For a more complete picture of local diversity, further sampling over the entire spring and summer months will most likely add new species. The optimal time of year for adult Odonata sampling in the northwestern part of the province seems to be from mid-July to mid-August. Another way of sampling in the future would be to do more aquatic netting to obtain Odonata in the larval stage, and visiting more sites in subsequent years. ASDPWP sites with the characteristics and traits known to support high species diversity of Odonata in adjacent areas in Canada, instead proved to have large numbers of individuals of low to medium diversity. Species to look for in ASDPWP are: Aeshna septentrionalis (Azure Darner), Somatochlora brevicincta (Quebec Emerald), S. hudsonica (Hudsonian Emerald), $S$. septentrionalis (Muskeg Emerald), and Sympetrum costiferum (Saffron-winged Meadowhawk).

\section{Acknowledgements}

Critical funding was graciously provided by the Saskatchewan Heritage Foundation and Royal Saskatchewan Museum. Peter Jonker, of the University of Saskatchewan, was instrumental in assisting with the funding agencies and also took care of the logistics for transport to the park from Fonddu-lac. Peter patiently answered many questions and provided critical survival, safety and specialised camping equipment. Chris Goode and George Bihun provided the use of a satellite phone, as well as a permit to collect insects in the park. It was Keith Roney from the RSM who first mentioned this particular area as he had previously been there with an expedition in 1981. Keith also provided an additional malaise trap and other field collecting equipment as well as preserving fluids and storage boxes for the specimens. And finally I would like to thank Ron Hooper for assistance with the logistics for this trip as well as his companionship at base camp and on excursions in the field.

1.ACORN, J. 2001. Tiger Beetles of Alberta, Killers on the Clay, Stalkers on the Sand. University of Alberta Press, Edmonton.

2.FUNG, K. 1999. Atlas of Saskatchewan. University of Saskatchewan, Saskatoon.

3. HUTCHINGS, G.E. 2004. Eight new species or previously unreported species of odonata (dragonflies) for Saskatchewan. Blue Jay 62(2): 98-103

4. HUTCHINGS, G.E. 2003. A list of the Odonata of Athabasca Sand Dunes Provincial Wilderness Park, Saskatchewan. Argia, The News Journal of the Dragonfly Society of the Americas 14(4): 5-8

5. HUTCHINGS, G.E. 2002. Three New Species of Odonata for Saskatchewan, Canada. Argia, The News Joumal of the Dragonfly Society of the Americas 13(4): $5-7$

6. JONKER, P. M. and J. S. ROWE. 2001. The Sand Dunes of Lake Athabasca, Your Adventure in Learning. University of Saskatchewan Extension Press, Saskatoon.

7. PAULSON, D. R., and S. W. DUNKLE. 1999. A checklist of North American Odonata, including English name, etymology, type locality, and distribution. Occ. Pap. Slater Mus. Nat. Hist., No. 56: $1-86$. 
8. PARKER, D. The Saskatchewan Aquatic Insect Pages. http://www.usask.ca/biology/skabugs/ dragon/odonata.html. [Accessed March 30, 2004], 1999.

9. RONEY, K. and J. DUNCAN. 2000. Compiled List of The Odonata of Saskatchewan.

10. WALKER, E. M. 1955. The Odonata of Canada and Alaska. Vol. I. U. of Toronto Press., Toronto.
11. WALKER, E. M. 1958. The Odonata of Canada and Alaska. Vol. II. U. of Toronto Press, Toronto.

12. WALKER, E. M. and P.S. Corbet. 1975. The Odonata of Canada and Alaska. Vol III. U. of Toronto Press, Toronto.

\section{ACTIVIST OPTIONS}

Perhaps,

as only gophers can,

sensing our longing

to stick it to "the Man",

eliminate the eyesore,

the tiny rodent made its way

stealthily

guilelessly

through the chainlink,

with its ineffectual barbed wire topping,

and into the transformer,

into saboteur heaven,

onto the front page of the Herald (city section).

Yet the substation still stands:

featured view,

through the plants and stained glass,

of the living room

in which we sit snug,

lattes in hand,

listening to Handel,

admiring the ravens,

dwellers among the high girders,

who raise their young in high-tension safety,

daring the Man

to climb on up

and deconstruct

their nest of sticks among the stays, and live to croak another day. 


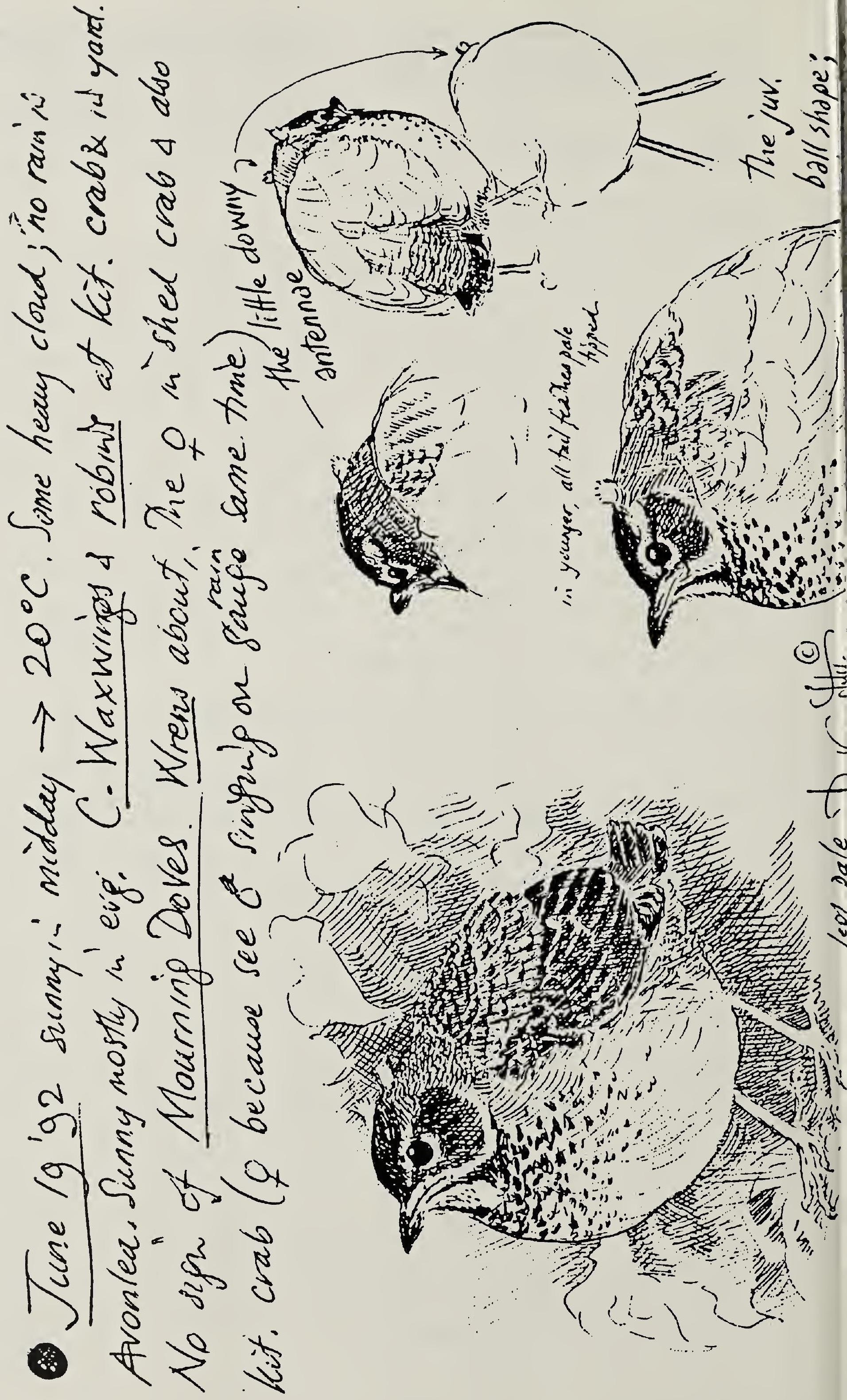


